\title{
Analisis Pengembangan Kecamatan Topoyo Sebagai Daerah Penyangga di Kabupaten Mamuju Tengah Berbasis Potensi Wilayah
}

\author{
Haerunniza, Nur Syam AS dan Fadhil Surur \\ Teknik Perencanaan Wilayah dan Kota Fakultas Sains dan Teknologi \\ UIN Alauddin Makassar \\ e-mail : haerunnizaabidin@gmail.com
}

\begin{abstract}
Abstrak-Kecamatan Topoyo merupakan satu dari lima kecamatan yang ada di Kabupaten Mamuju Tengah dengan luas sebesar $884,80 \mathrm{~km}^{2}$. Kecamatan ini memiliki potensi sumber daya alam yang melimpah dari segi perkebunan yang dapat dikembangkan menjadi kawasan industi perkebunan, hal ini dilakukan agar masyarakat yang berada di Kecamatan Topoyo dan sekitarnya tidak sepenuhnya bergantung pada kota besar dan dapat mengubah fungsinya sebagai daerah penyangga di Kabupaten Mamuju Tengah. Analisis yang digunakan adalah Analisis Keterkaitan Hubungan Fungsional dan Analisis Skala Likert dengan variabel yang diteliti meliputi kebijakan pemerintah, potensi wilayah, dan industri. Hasil penelitian menunjukkan bahwa kebijakan pemerintah, sumber daya alam, sosial ekonomi, dan industri memili nilai peluang padaangka 84 $\%$, sehingga secara keseluruhan sangat mendukung untuk dikembangkan menjadi kawasan industri. Konsep yang ditawarkan adalah konsep Ecology Industrial Parks (EIP) adalah sebuah komunitas industri dan bisnis yang terletak dalam satu kawasan yang saling terintegrasi membentuk komunitas.
\end{abstract}

Kata Kunci-pengembangan, potensi, penyangga

\section{PENDAHULUAN}

$\mathrm{B}$ ERKEMBANGNYA Kota Mamuju sebagai Ibukota Provinsi Sulawesi Barat, memicu tumbuhnya wilayah baru seperti wilayah permukiman dan wilayah komersil [1]. Hal ini sebagai imbas dari berkembangnya jumlah populasi di Kabupaten Mamuju. Perkembangan wilayah tersebut menyebabkan pergeseran nilai dari wilayah yang sebelumnya kosong dan tidak potensial menjadi wilayah yang potensial dan strategis. Berdasarkan Peraturan Daerah Nomor 1 tahun 2014 tentang Rencana Tata Ruang Wilayah Provinsi Sulawesi Barat Tahun 2014-2034 disebutkan bahwa Kota Mamuju masuk dalam wilayah Pusat Kegiatan Nasional [2].

Tahun 2007 lahir sebuah gagasan tentang pembentukan Kabupaten Mamuju Tengah yang dituangkan salah satunya dalam Keputusan Dewan Perwakilan Rakyat Daerah Kabupaten Mamuju No. 17 Tahun 2007 Tanggal 31 Agustus 2007 tentang Persetujuan Pemekaran/Pembentukan Kabupaten Mamuju Tengah [3]. Pemekaran wilayah di Kabupaten Mamuju Tengah dapat menjadi salah satu langkah untuk menata tatanan ruang baru. Penataan ruang Kabupaten Mamuju Tengah bertujuan untuk mewujudkan pembangunan Kabupaten Mamuju Tengah secara merata, terpadu dan berkelanjutan dengan berbasis agrobisnis yang berwawasan lingkungan menuju masyarakat maju dan sejahtera [4]. Seperti yang kita ketahui bahwa dengan terjadinya pemekaran Kabupaten Mamuju Tengah berdampak baik dikarenakan mulai nampaknya ciri-ciri perkembangan perkotaan terutama di Kecamatan Topoyo.

Kecamatan Topoyo merupakan daerah penyangga (buffer zone) yang berbatasan langsung dengan Kecamatan Tobadak sebagai Ibukota Kabupaten Mamuju Tengah. Kecamatan Topoyo ialah satu dari lima Kecamatan yang ada di Kabupaten Mamuju Tengah, tingkat pertumbuhan perekonomian, fasilitas umum beserta kegiatan jasa pelayanan yang pesat berkat hasil pemekaran dari Kabupaten Mamuju menjadi Kabupaten Mamuju Tengah [5]. Penelitian ini dimaksudkan untuk menyusun kota baru Kecamatan Topoyo yang berdasar pada potensi-potensi yang ada, kemudian dikembangkan menggunakan konsep yang sesuai menurut potensi daerah tersebut. Hal ini dilakukan agar daerah berkembang yang berada di Kecamatan Topoyo Kabupaten Mamuju Tengah dan sekitarnya tidak sepenuhnya bergantung pada kota besar dan dapat pula mengurangi beban ibu kota Provinsi Sulawesi Barat. Hal ini sejalan dengan kerangka kutub pertumbuhan dalam wilayah Kabupaten Mamuju Tengah diaplikasikan dalam bentuk hierarki wilayah melalui sistem kota-kota untuk menjembatani antar desa dengan kota dengan harapan memperkecil perbedaan peluang kegiatan ekonomi sesuai potensi lokal dan pelayanan sosial [4]. Pada kasus yang sama potensi wilayah Kecamatan Sumur dan Cimanggu sebagai penyangga di wilayah Taman Nasional Ujung Kulon dikembangkan berdasarkan potensi lokal berupa kegiatan pertanian dan perkebunan [6]. Karena kawasan yang terencana dengan baik akan mengurangi terjadinya permasalahan ruang di masa mendatang dan menciptakan keselarasan dengan lingkungan alami. Pengembangan daerah penyangga harus disejajarkan dengan percepatan transformasi ekonomi untuk pemacuan kemajuan peradaban dan tingkat kehidupan masyarakat [7]. Tujuan dari penelitian ini adalah mengindentifikasi faktor yang mendukung peran Kecamatan Topoyo sebagai daerah penyangga pengembangan potensi wilayah di Kabupaten Mamuju Tengah dan menyusun konsep pengembangan berdasarkan potensi wilayah di kecamatan tersebut.

\section{METODE PENELITIAN}

Penelitian ini dilakukan di Sulawesi Barat khususnya di Kabupaten Mamuju Tengah Kecamatan Topoyo dikarenakan perkembangan permukiman dan kegiatan aktivitas di Kecamatan Topoyo yang mulai pesat sebagai daerah penyangga. 


\section{A. Variabel Penelitian}

Variabel dapat diartikan ciri dari individu, objek, gejala, peristiwa yang dapat diukur secara kuantitatif ataupun kualitatif. Adapun variabel yang digunakan dalam penelitian ini, yaitu:

Tabel 1.

Variabel Penelitian

\begin{tabular}{lll}
\hline \hline \multicolumn{1}{c}{ Variabel } & \multicolumn{1}{c}{ Indikator } \\
\hline Kebijakan & 1. & RTRW Prov. Sulawesi Barat \\
pemerintah & 2. & RTRW Kabupaten Mamuju \\
& Tengah \\
& 1. & Sumber Daya Alam \\
& & 1) Produktifitas Lahan \\
& 1) Kualitas produk \\
& 2. & Sumber Daya Manusia \\
& & 1) Pengetahuan \\
Potensi Wilayah & 2) Keterampilan \\
& 3. & Sosial ekonomi \\
& & 1) Pelibatan tenaga kerja \\
& & 2) Kerja sama \\
& & 3) Pemasaran produk \\
& & 4) Pendapatan \\
& 1. & Modal \\
Pemusatan & 2. & Teknologi \\
Industri & 3. & Bahan baku \\
& 4. & Transportasi \\
& 5. & Tenaga kerja \\
& 6. & Pasar dan \\
& 7. & Infrastruktur \\
\hline \hline
\end{tabular}



Gambar 1. Peta Lokasi Penelitian

\section{B. Teknik Penarikan Sampel}

Teknik penarikan menggunakan random sampling yaitu teknik penarikan secara acak dinilai mampu memberikan informasi yang dibutuhkan [8]. Populasi yang menjadi terget dalam penelitian ini adalah jumlah penduduk Kecamatan Topoyo yang telah mewakili kelompok masyarakat yang terlibat langsung dalam kegiatan pembangunan antara lain perangkat daerah, pemerintah kecamatan, asosiasi dan tokoh masyarakat. Berdasarkan Teknik pengembilan sampel tersebut maka diperoleh sampel sebanyak 100 responden (Rumus
Slovin jumlah penduduk 31.880) orang yang memiliki pengetahuan dan informasi terkait dengan tujuan penelitian.

\section{Teknik Analisis Data}

Dalam penelitian ini analisis yang digunakan dalam penelitian yaitu Analisis Keterkaitan Hubungan Fungsional untuk mengetahui jenis kegiatan yang akan direncanakan di Kecamatan Topoyodan Analisis Skala Likert untuk mengetahui faktor-faktor pendukung Kecamatan Topoyo sebagai daerah pemusatan industri.

\section{Analisis Keterkaitan Hubungan Fungsional}

Analisis keterkaitan hubungan fungsional adalah analisis yang menjelaskan tingkat keterkaitan fungsional yang didasarkan pada pola interaksi antara elemen atau fungsi pemanfaatan maupun jenis kegiatan yang akan direncanakan. Adapun penilaian mengenai tingkat keterkaitan hubungan fungsional terdiri dari kuat, sedang, lemah didasarkan pada pola interaksi kegiatan. Elemen-elemen yang mempunyai hubungan fungsi yang kuat, ketentuan pemanfaatannya diizinkan, sedangkan elemen-elemen yang mempunyai hubungan fungsi yang sangat sedang lemah, ketentuan pemanfaatannya bisa berupa bersyarat terbatas, bersyarat tertentu, atau bahkan tidak diperbolehkan, tergantung jenis kegiatan yang akan dikembangkan pada daerah tersebut. Meskipun demikian, jika dalam matriks hubungan fungsionalnya dinyatakan kuat, jenis kegiatan pada daerah tersebut tetap menjadi tolak ukur pertimbangan utama. Pengukuran tingkat hubungan fungsional didasarkan pada beberapa aspek yang menjadi varibel dalam penelitian ini. Tinjauan dari aspek kebijakan didasarkan pada dokumen RTRW Kabupaten Mamuju Tengah, aspek potensi wilayah mencakup sumberdaya alam, sumberdaya manusia dan sosial ekonomi, sedangkan pemusatan industri difokuskan pada kegiatan industri yang menjadi kegiatan utama di wilayah tersebut.

\begin{tabular}{|l|}
\hline RTRW \\
\hline SDA \\
\hline SDM \\
\hline Sosial Ekonomi \\
\hline Industri \\
\hline
\end{tabular}

Gambar 2. Matriks Hubugan Fungsional Antar Varibel

Keterangan :

- Hubungan Kuat ๑ Hubungan Sedang oHubungan Lemah

\section{Analisis Skala Likert}

Skala Likert digunakan untuk mengatur sikap, pendapat, dan persepsi seseorang atau sekelompok orang tentang fenomena sosial. Dari pengertian tersebut, maka dapat disimpulkan bahwa skala Likert dapat digunakan untuk mengukur sikap seseorang dengan menyatakan setuju atau tidak setuju terhadap subjek, objek atau kejadian tertentu [9]. Instrumen ini terdiri dari beberapa item penilaian mengenai kondisi sumber daya alam dan lingkungannya, kondisi sosial ekonomi, dan kedudukan strategisnya [10]. Adapun nilai ratarata skor yang selanjutnya akan dikategorikan pada rentang skor berikut ini : 
Nilai Tertinggi $=5$

Nilai Terendah $=1$

Berdasarkan nilai tertinggi dan terendah tersebut, maka dapat ditentukan rentang interval yaitu nilai tertinggi dikurangi nilai terendah, dengan cara rentang interval dibagi dengan jumlah nilai.

$$
\text { Rentang skor }=\frac{\text { nilai tertinggi }- \text { nilai terendah }}{\text { Jumlah nilai }(. . . \text { ii })}
$$

Untuk variabel independenSistem Pengendalian Internal dengan 17 indikator, nilai tertinggi dikalikan dengan 5 dan nilai terendah dikalikan dengan 1 , sehingga

1. Nilai tertinggi $17 \times 5=85$

2. Nilai terendah $17 \times 1=17$

Lalu kelas interval sebesar $((85-17) / 3)=22,6$ maka penulis menentukan kriterianya sebagai berikut :

Tabel 2.

Kategorisasi Penilaian

\begin{tabular}{clcc}
\hline \hline No. & Uraian Penilaian & Kriteria & Nilai \\
\hline 1 & Tidak Mendukung & 1 & $7-39,6$ \\
2 & Kurang Mendukung & 3 & $39,7-62,3$ \\
3 & Faktor Mendukung & 5 & $62,4-100$ \\
\hline \hline
\end{tabular}

Keterangan Pembobotan:

- Tidak mendukung apabila indikator yang dinilai dianggap mendukung untuk dikembangkan di Kecamatan Topoyo Kabupaten Mamuju Tengah

- Kurang mendukung apabila indikator yang dinilai dianggap kurang mendukung untuk dikembangkan di Kecamatan Topoyo Kabupaten Mamuju Tengah

- Faktor mendukung apabila indikator yang dinilai dianggap mendukung untuk dikembangkan di Kecamatan Topoyo Kabupaten Mamuju Tengah.

Hasil yang diperoleh kemudian dibobotkan berdasarkan wawancara secara tertutup pada 10 orang narasumber dari perangkat daerah, akademisi dan pemerintah kecamatan. Sehingga diperoleh pembagian bobot kebijakan pemerintah (20), potensi wilayah (40) dan kegiatan industri (20).

\section{Penarikan Kesimpulan}

Penarikan kesimpulan berdasarkan hasil Keterkaitan Hubungan Fungsional dan Analisis Skala Likert dengan didukung oleh teori-teori yang berkaitan dengan masalah yang diteliti. Rangkaian analisis dan pengujian hipotesis yang telah dilakukan secara manual, maupun dengan alat bantu, memberikan dasar untuk penarikan kesimpulan atas penelitian yang dilakukan penulis. Berdasarkan kesimpulan tersebut, selanjutnya penulis akan memberi pandangan mengenai hubungan yang terdapat dari variabel-variabel penelitian.

\section{HASIL DAN DISKUSI}

\section{A. Gambaran Umum Wilayah Kecamatan Topoyo}

\section{Letak Geografis dan Administrasi}

Kecamatan Topoyo merupakan satu dari lima kecamatan yang ada di Kabupaten Mamuju Tengah dengan luas sebesar $884,80 \mathrm{~km}^{2}$. Secara administrasi Kecamatan Topoyo berbatasan langsung dengan Kecamatan Karossa sebelah utara, Kecamatan Tobadak dan Kecamatan Budong budong di sebelah selatan, Selat Makassar di sebelah barat dan sebelah timur Provinsi Sulawesi Selatan.

Kecamatan Topoyo terbagi atas 15 (lima belas) desa yaitu Budong-Budong, Pangalloang, Topoyo, Paraili, Kabubu, Tumbu, Sinabatta, Waeputeh, Tappilina, Salupangkang IV, Bambamanurug, Salupangkang, Tangkau, Tabolang, dan Salule'bo.

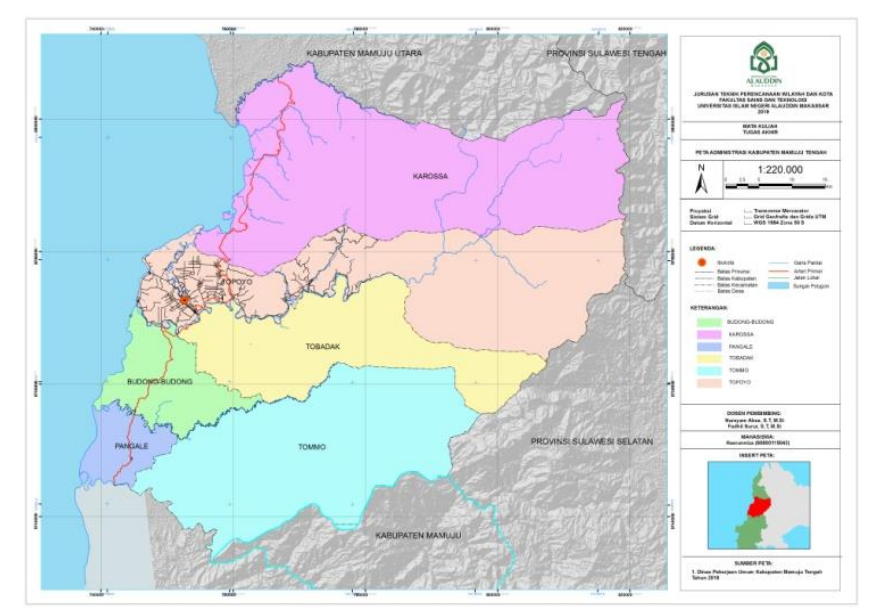

Gambar 3. Peta Administrasi Kecamatan Topoyo

Tabel 3.

Luas Wilayah Menurut Desa Di Kecamatan Topoyo, Tahun 2017

\begin{tabular}{ccc}
\hline \hline Desa & Luas $\left(\mathrm{Km}^{2}\right)$ & Persentase \\
\hline Budong-Budong & 17,70 & 2,00 \\
Pangalloang & 14,15 & 1,60 \\
Topoyo & 8,34 & 0,94 \\
Paraili & 6,20 & 0,70 \\
Kabubu & 3,89 & 0,44 \\
Tumbu & 16,72 & 1,89 \\
Sinabatta & 17,95 & 2,03 \\
Waeputeh & 7,87 & 0,89 \\
Tappilina & 7,32 & 0,83 \\
Salupangkang IV & 10,91 & 1,23 \\
Bambamanurung & 4,76 & 0,54 \\
Salupangkang & 10,93 & 1,24 \\
Tangkau & 3,38 & 0,38 \\
Tabolan & 41,42 & 2,68 \\
Salule'bo & 713,27 & 80,61 \\
Topoyo & 884,80 & 100,00 \\
\hline \hline
\end{tabular}

Berdasarkan data tersebut Desa Salule'bo merupakan desa terluas dari desa yang ada di Kecamatan Topoyo dengan luas sebesar 713,27 persentase 80,61 \%. Sedangkan desa yang memiliki luas paling terkecil yaitu Desa Tangkau dengan luas 3,38 dan persentase $0,38 \%$. Untuk lebih jelas dapat dilihat pada peta pembagian wilayah administrasi di Kecamatan Topoyo.

2. Perkembangan Penduduk 
Jumlah penduduk Kecamatan Topoyo pada tahun 2017 sebanyak 31.888 jiwa yang tersebar di 15 (lima belas) desa. Dari lima belas kecamatan yang mempunyai jumlah penduduk terbesar yaitu Desa Topoyo dengan 7.181 jiwa dan Desa Salupangkang IV merupakan desa yang memiliki jumlah penduduk terkecil yaitu 416 jiwa.

Tabel 4.

Jumlah Penduduk Di Kecamatan Topoyo Tahun 2017

\begin{tabular}{cccc}
\hline \hline Desa & Jumlah & Kepadatan & Persentase \\
\hline Budong-Budong & 2340 & 132,20 & 7,34 \\
Pangalloang & 1410 & 99,65 & 4,42 \\
Topoyo & 7181 & 861,03 & 22,52 \\
Paraili & 1324 & 213,55 & 4,15 \\
Kabubu & 1182 & 303,86 & 3,71 \\
Tumbu & 2879 & 172,19 & 9,03 \\
Sinabatta & 997 & 55,54 & 3,13 \\
Waeputeh & 1658 & 210,67 & 5,20 \\
Tappilina & 1533 & 209,43 & 4,81 \\
Salupangkang IV & 416 & 38,13 & 1,30 \\
Bambamanurun & 1036 & 217,65 & 3,25 \\
Salupangkang & 1983 & 181,43 & 6,22 \\
Tangkau & 886 & 262,13 & 2,78 \\
Tabolang & 2921 & 70,52 & 9,16 \\
Salule'bo & 4142 & 5,81 & 12,99 \\
Topoyo & 31.888 & 36,04 & 100,00 \\
\hline \hline
\end{tabular}

\section{B. Analisis Keterkait an Hubungan Fungsional}

Penilaian mengenai tingkat keterkaitan hubungan fungsional yang kuat, sedang, lemah didasarkan pada pola interaksi antar elemen-elemen kegiatan yang ada dalam pengembangan kawasan Kecamatan Topoyo. Dalam hal ini, elemen-elemen yang mempunyai hubungan fungsi yaitu :

- RTRW Kab. Mamuju Tengah

- Sumber Daya Alam

- Sumber Daya Manusia

- Sosial Ekonomi dan Industri

Berdasarkan kelima elemen tersebut nantinya akan disandingkan dengan hubungan fungsional terkait terhadap RTRW Kabupaten Mamuju Tengah yang terdiri dari tiga hubungan yaitu hubungan kuat, sedang, dan lemah. Lebih jelasnya sebagai berikut:

- Hubungan kuat jika indikator penilaian memiliki hubungan yang erat terhadap RTRW Kab. Mamuju Tengah atau terhadap indikator penilaian lainnya dan diberi skor 5

- Hubungan sedang jika penilaian hubungan kurang erat atau biasa- biasa saja terhadap RTRW Kab. Mamuju Tengah atau terhadap indikator penilaian lainnya dan diberi skor 3

- Hubungan lemah jika indikator penilaian tidak memiliki keterkaitan hubungan sama sekali, dan diberi skor 1

Lebih jelasnya dapat dilihat dalam Matriks Hubungan Fungsional Antar Kegiatan berikut:

\begin{tabular}{|l|}
\hline RTRW Kab. Mamuju \\
\hline SDA \\
\hline SDM \\
\hline Sosial Ekonomi \\
\hline industry
\end{tabular}

Gambar 4. Hasil analisis matriks hubugan fungsional

Keterangan:

- Hubungan Kuat $\bullet$ Hubungan Sedang $\odot$ Hubungan Lemah

Berdasarkan matriks nilai hubungan RTRW Kabupaten Mamuju Tengah antar SDA, SDM, sosial ekonomi dan industri yaitu memiliki hubungan kuat dengan hubungan yang paling lemah yaitu sumber daya manusia yang kurang mendukung dari segi penduduk tenaga kerja yang belum memiliki pekerjaan dan menyebabkan nilai hubungan lemah terhadap sumber daya alam, sosial ekonomi dan industri.

\section{Analisis Peluang Pengembangan Wilayah Kecamatan Topoyo Sebagai Kawasan Industri}

1. Kebijakan pemerintah

a. RTRW Provinsi Sulawesi Barat tahun 2014-2034 dikategorikan sebagai faktor mendukung, dikarenakan terdapat dalam RTRW Sulawesi Barat sebagai kawasan industri

b. RTRW Kabupaten Mamuju Tengah Tahun 2017-2037 dikategorikan sebagai faktor kurang mendukung, dikarenakan tidak sebutkan sebagai pusat kegiatan industri melainkan sebagai peruntukan industri kecil dan mikro

2. Potensi Wilayah

a. Sumber Daya Alam, Kecamatan Topoyo memiliki kekayaan alam yang melimpah membuat masyarakat di memanfaatkan kondisi tersebut dengan baik serta mempunyai nilai ekonomis tinggi komoditas unggulan seperti adalah kelapa sawit, kakao, kalapa dalam, cengkeh dan lada tersebut mempunyai peluang untuk pasar dalam maupun luar negeri. Bahan pelitian dari Sumber Daya Alam ini terdiri dari beberapa penilaian yaitu: produktifitas lahan dan kualitas produksi yang mendukung untuk dikembangkan

b. Sumber Daya Manusia, Salah satu yang terpenting dan berpengaruh pada suatuproses pembangunan dan pengembangan wilayah yaitu penduduk, karena penduduk merupakan salah satu objek yang berperan dalam pembangunan. Bahan pelitian dari terdiri dari tenaga kerja, pengetahuan dan keterampilan yang kurang mendukung untuk dikembangkan dikarenakan tingginya jumlah penduduk yang tidak memiliki pekerjaan, pengetahuan dan keterampilan dalam mengolah sumber daya alam di Kecamatan Topoyo.

c. Sosial Ekonomi terdiri dari beberapa penilaian seperti: kerja sama yang mendukung dikarenakan kerjasama antar masyarakat berjalan baik. Pendapatan masyarakat yang meningkatkan dan dikategorikan sebagai faktor mendukung. Pemasaran produk dikategorikan sebagai faktor kurang mendukung dikarenakan pemasaran diolah hingga menjadi produk mentah saja. 
3. Pemusatan industri, terdiri dari beberapa indicator penelitian yang akan menjadi bahan masukan pengembangan Kecamatan Topoyo seperti modal, teknologi, bahan baku, transportasi, pelibatan tenaga kerja, pasar, dan infrastruktur yang mendukung untuk dikembangkan lain halnya dengan teknologi, yang mana teknologi berkembang dengan pesat tetapi tidak dimanfaatkan dengan baik dan dikategorikan sebagai faktor kurang mendukung.

Tabel 5.

Penilaian Indikator Kebijakan

\begin{tabular}{ccc}
\hline \hline Indikator & $\begin{array}{c}\text { RTRW } \\
\text { Sulawesi } \\
\text { Barat }\end{array}$ & $\begin{array}{c}\text { RTRW } \\
\text { Mamuju } \\
\text { Tengah }\end{array}$ \\
\hline Bobot & 50 & 50 \\
Kriteria & 5 & 3 \\
Total & 250 & 150 \\
\hline $\begin{array}{c}\text { Keterangan (\%) } \\
\text { (hasil bobot * kriteria } \\
\text { / total tertinggi * 100) }\end{array}$ & $400: 500 \times 100=80$ \\
\hline Nilai & \multicolumn{2}{c}{16} \\
\hline \hline
\end{tabular}

Tabel 6.

Penilaian Indikator Potensi Wilayah

\begin{tabular}{cccc}
\hline \hline Indikator & SDA & SDM & $\begin{array}{c}\text { Sosial } \\
\text { Ekonomi }\end{array}$ \\
\hline Bobot & 25 & 37,5 & 37,5 \\
Kriteria & 10 & 7 & 13 \\
Total & 125 & 87,5 & 162 \\
\hline $\begin{array}{c}\text { Keterangan }(\%) \\
\text { (hasil bobot * kriteria }\end{array}$ \\
$\begin{array}{c}\text { /total tertinggi * 100) } \\
\text { Nilai }\end{array}$ \\
\hline \hline
\end{tabular}

Tabel 7.

Penilaian indikator industri

Modal, bahan

baku,

\begin{tabular}{|c|c|c|}
\hline \multicolumn{3}{|c|}{ Penilaian indikator industri } \\
\hline Indikator & $\begin{array}{l}\text { Modal, bahan } \\
\text { baku, } \\
\text { transportasi, } \\
\text { tenaga kerja, } \\
\text { pasar, } \\
\text { infrastruktur }\end{array}$ & Teknologi \\
\hline Bobot & 85,8 & 14,3 \\
\hline Kriteria & 30 & 3 \\
\hline Total & 429 & 42,9 \\
\hline $\begin{array}{l}\text { Keterangan }(\%) \\
\text { (hasil bobot * kriteria } \\
\text { / total tertinggi * 100) }\end{array}$ & \multicolumn{2}{|c|}{$375: 500 \times 100=75$} \\
\hline Nilai Keseluruhan & \multicolumn{2}{|c|}{$84 \%$} \\
\hline
\end{tabular}

Berdasarakan tabel diatas kondisi pengembangan yang ada di Kecamatan Topoyo dengan melihat potensi wilayah dimana kebijakan pemerintah, sumber daya alam yang melimpah, sosial ekonomi dan hasil produksi industri maka mendorong Kecamatan Topoyo untuk mengembangkan potensi perkebunan dan produksi industri khususnya komoditi kelapa sawit. Agar nantinya dapat menyerap banyaknya sumber daya manusia serta menyediakan lapangan pekerjaan yang semula bertujuan ke ibu kota Provinsi Sulawesi Barat dapat mengalihkan perhatiannya ke Kecamatan Topoyo. Dengan didukung oleh tenaga kerja yang direkrut dari masyarakat setempat maka masalah ketenagaan di Kecamatan Topoyo dapat teratasi. Karena untuk saat ini komoditas perkebunan mampu memberikan kontribusi nyata terhadap pendapatan daerah dan pendapatan masyarakat.

\section{Konsep Pengembangan Kecamatan Topoyo Sebagai Daerah Penyangga Berbasis Potensi Wilayah}

Melihat kondisi yang ada di Kecamatan Topoyo pengembangan yang berbasis potensi wilayah maka konsep yang ditawarkan sesuai dengan pengembangan Kecamatan Topoyo berbasis potensi perkebunan dan produksi industry adalah konsep Ecology Industrial Parks (EIP) yang memiliki pengertian yaitu sebuah komunitas industri dan bisnis yang terletak dalam satu kawasan yang saling terintegrasi membentuk komunitas yang bertujuan pada peningkatan kualitas lingkungan, ekonomi, sosial dan kemampuan dalam mengelola lingkungan serta sumber daya yang dihasilkan dari sebuah kawasan. Komunitas terbentuk mencapai kondisi kinerja secara sosial, ekonomi dan lingkungan yang didukung dengan sumber daya alam untuk mencapai keuntungan secara kolektif. Aktivitas ekonomi dilakukan di dalam sebuah kawasan melalui kegiatan peningkatan nilai produk melalui proses produksi yang berlandaskan pada nilai-nilai kelestarian lingkungan atau ekologi yang bermanfaatan dan berkelanjutan. Eco Industrial Park merupakan kawasan industri yang menyatu atau terintegrasi dalam satu unit kawasan yang didukung ketersediaan bahan baku, pengelolaan limbah, ketersediaan sumber energy yang sistem dinamik lingkungannya menggunakan kembali bahan/sisa dan pemanfaatan limbah yang memberikan dampak bagi lingkungan. Kawasan EIP (Eco Industrial Park) yang nantinya berlokasi di Kecamatan Topoyo dirancang sesuai dengan kebutuhan penduduk di wilayah tersebut denganmemanfaatkan sumber daya (informasi, material, air, energi, infrastruktur, danhabitat alam) secara bersama-sama, meningkatkan kualitas ekonomi dan lingkungan, serta meningkatkan sumber daya manusia bagi kepentingan bisnis dan juga masyarakat sekitarnya.

Konsep ini sangat tepat diterapkan di Kecamatan Topoyo dengan mengembangkan komunitas bisnis yang bekerjasama antarperusahaan serta masyarakat di suatutempat. lokasi terkhusus pada pembangunan kegiatan industri yaitu Desa Salulekbo yang jauh dari permukiman penduduk, ada juga desa yang termasuk yaitu Desa Tumbu, Salupangkang IV, Waiputeh, Bambamanurung, Tappilina dan Desa Pangalloang yang didukung oleh ketersediaan bahan bakuyang melimpah. Agar penerapan konsep EIP dapat berhasil, maka lokasi yang ada di Kecamatan Topoyo setidaknya memenuhi tiga kondisi, yaitu keseimbangan antara permintaan dan penawaran produk samping, hubunganantar perusahaan didasarkan pada kedekatan perusahaan, dan adanya peraturan yang mendukung kerjasama perusahaan. Didorong dengan prinsip keberlanjutan berupa sosial, ekonomi dan lingkungan. Pengembangan kawasan ini diawali pemerintah melalui gerakan pencapaian pembangunan berkelanjutan dengan minimasi dampak aktivitas industri terhadap lingkungan. Gerakan pengembangan tersebut ini dapat dimulai dari pemerintah Kabupaten Mamuju Tengah melalui proses produksi industri 
yang berlandaskan pada nilai-nilai kelestarian lingkungan atau ekologi yang bermanfaat dan berkelanjutan. Serta yang paling utama dapat membantu mengurangi jumlah penduduk yang tidak memiliki pekerjaan di Kecamatan Topoyo dan sekitarnya dan membantu menekan perpindahan volume penduduk keibu kota Provinsi Sulawesi Barat dan meningkatkan kesejahteraan masyarakat setempat.
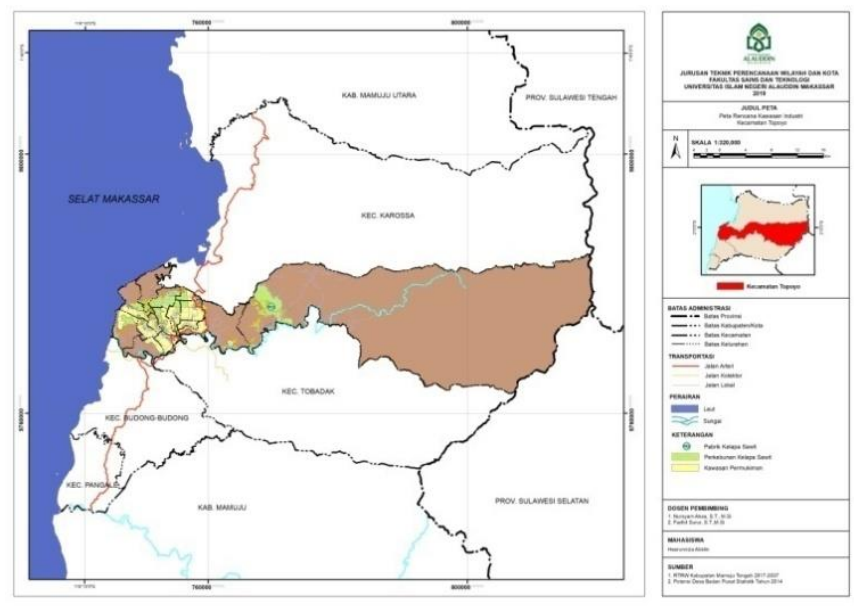

Gambar 5. Peta Rencana Kawasan Industri

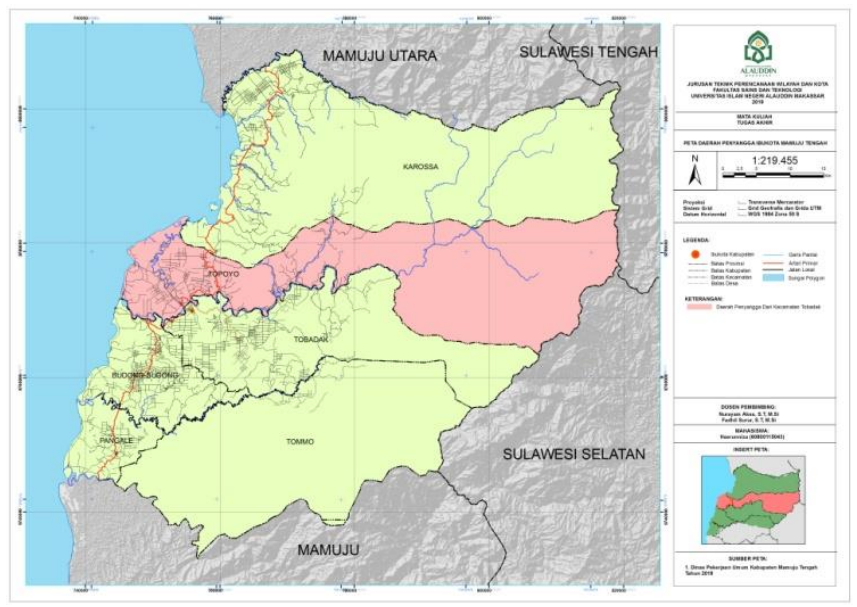

Gambar 6. Peta Daerah Penyangga Kecamatan Topoyo

\section{KESIMPULAN/RINGKASAN}

Faktor yang mendukung perkembangan Kecamatan Topoyo sebagai daerah penyangga yang berbasis potensi di Kabupaten Mamuju Tengah yaitu kebijakan pemerintah yang menetapkan Kawasan Kecamatan Topoyo Kabupaten Mamuju Tengah sebagai kawasan agroindustri, potensi sumber daya alam yang melimpah di dorong dengan produktifitas lahan dan kualitas produk yang baik, Faktor - faktor tersebut $84 \%$ mendukung untuk dikembangkan sebagai kawasan potensi perkebunan dan kawasan industri.

Adapun konsep yang ditawarkan berdasarkan potensi wilayah Kecamatan Topoyo sebagai kawasan industri yaitu konsep Ecology Industrial Parks Parks yang merupakan konsep industri dan bisnis yang terletak dalam satu kawasan yang saling terintegrasi membentuk komunitas bisnis yang bekerjasama antar perusahaan serta masyarakat yang secara efisien saling memperoleh keuntungan ekonomi. Dengan konsep yang ditawarkan semoga kedepannya menjadikan Kecamatan Topoyo dapat mengembangkan potensi kawasan industrinya dan bersaing dengan daerah lainnya yang mampu mensejahterakan masyarakatnya.

\section{DAFTAR PUSTAKA}

[1] A. Irawadi, B. Juanda, and K. Munibah, "Analisis Kemiskinan Spasial dan Kaitannya dengan Sertifikasi dan Penggunaan Lahan Pertanian di Kabupaten Mamuju," TATALOKA, 2020, doi: 10.14710/tataloka.22.1.70-82.

[2] M. Musyafir, P. Astomo, and F. Rasyid, "TINJAUAN YURIDIS TERHADAP KEBIJAKAN PEMERINTAH KABUPATEN MAMUJU TERKAIT PENATAANRUANG WILAYAH," J. Huk. Unsulbar, 2020, doi: 10.31605/j-law.v2i1.590.

[3] S. Maldun, "Analisis Implementasi Kebijakan Pemekaran Daerah di Kabupaten Mamuju Utara," Semin. Nas. "Revolusi Ment. dan Kemandirian Bangsa Melalui Pendidik. Ilmu- ilmu Sos. dalam Menghadapi MEA 2015, ” 2016.

[4] N. Nasriaty, "IMPLEMENTASI KEBIJAKAN RENCANA TATA RUANG WILAYAH DI KABUPATEN MAMUJU UTARA," Katalogis, 2016.

[5] M. Zainuddin, "Implikasi Kolaborasi Pemerintah Daerah Dan Pihak Swasta Terhadap Produksi Petani Kelapa Sawit,” J. Sosio Sains, 2019.

[6] A. Paramita, L. Sundawati, and D. R. Nurrochmat, "Strategi Kebijakan Pemanfaatan Hasil Hutan Bukan Kayu," Risal. Kebijak. Pertan. dan Lingkung., 2017.

[7] "Pengembangan Daerah Penyangga sebagai Upaya Pengendalian Arus Urbanisasi," Anal. Kebijak. Pertan., 2017, doi: 10.21082/akp.v4n4.2006.328-342.

[8] M. L. Patten, M. C. Galvan, M. L. Patten, and M. C. Galvan, "Random Sampling," in Proposing Empirical Research, 2019.

[9] R. W. Emerson, "Likert Scales," J. Vis. Impair. Blind., 2017, doi: 10.1177/0145482x1711100511.

[10] D. Kho, "Pengertian Skala Likert dan Cara Menggunakan Skala Likert," Teknik Elektronika, 2018. 